\title{
Local Genius dan Implementasi Pengarusutamaan Gender pada Pemerintahan Kabupaten di Sumatera Utara
}

\author{
${ }^{1}$ TENGKU IRMAYANI, ${ }^{2}$ NURBANI, ${ }^{3}$ SABARIAH BANGUN \\ 1)2)3) Fakultas IImu Sosial dan IImu Politik, Universitas Sumatera Utara, Jl. Dr. Sofyan Nomor 1, Medan \\ ${ }^{1}$ tengku.irmayani@gmail.com; ${ }^{2}$ sun_banymonora@gmail.com; ${ }^{3}$ sabariah_bangun@yahoo.com
}

\begin{abstract}
The value of local genius have a big role to influence the public's attitudes and participation, in order to create an equal role between men and women in government policies. Therefore, we need to identify which local genius have an added value, so that the local government could put more interest on it when they make the policy (JPJMP). This research was conducted in two areas in Sumatera Utara, Kabupaten Karo and Kabupaten Nias Selatan with the qualitative method. The data collection was done by in-depth interviews with the institution that responsible to implement the responsive gender budget (ARG), community leaders, and traditional leaders. Focused group discussion also done to synergize the opinion that was founded in the interview. The results of this research was concluded that the regional government of Kabupaten Karo and Kabupaten Nias Selatan still have not identify the local genius that have added value and to be developed into the policy making of RPJMP.
\end{abstract}

Keyword: implementation, gender mainstream, local genius, policy.

\begin{abstract}
Abstrak. Untuk menciptakan kesetaraan peran antara laki-laki dan perempuan dalam kebijakan pemerintah, dalam hal ini local genius sangat berperan dan penentu bagi sikap dan partisipasi masyarakat. Oleh karenanya perlu diidentifikasi local genius yang mempunyai nilai lebih sehingga nantinya pemerintah daerah dapat lebih memperhatikannya dalam RPJMD. Penelitian ini dilakukan di dua daerah yang ada di Sumatera Utara yaitu: Kabupaten Karo dan Kabupaten Nias Selatan dengan metode kualitatif. Untuk mengumpulkan data yang dibutuhkan peneliti melakukan wawancara mendalam dengan lembaga implementasi ARG maupun lembaga yang menggerakkan implementasi ARG, tokoh-tokoh masyarakat dan tokoh-tokoh adat. Untuk lebih mensinkronkan apa yang telah didapat dari hasil wawancara selanjutnya dilaksanakan FGD. Dari hasil penelitian dapat disimpulkan pemerintah daerah Karo dan Nias Selatan belum melakukan identifikasi local genius mana yang memiliki nilai lebih dan dapat dikembangkan dalam RPJMD.
\end{abstract}

Kata kunci: implementasi, pengarusutamaan, gender, local genius, kebijakan.

\section{Pendahuluan}

Local genius dalam suatu komunitas masyarakat memegang peranan penting untuk pengendalian dan memberikan arah terhadap perkembangan kebudayaan masyarakat. Dalam kebudayaan inilah teridentifikasi dan termanifestasi kepribadian suatu masyarakat yang tercermin dalam orientasi yang menunjukkan pandangan hidup serta sistem nilai dalam persepsi untuk melihat dan menanggapi dunia luarnya, sehingga pola serta sikap hidup yang diwujudkan dalam tingkah-laku sehari-hari melalui gaya hidup yang mewarnai kehidupannya. Local genius sebagai suatu nilai budaya, yang selalu dihubungkan dengan nilai baik yang dipertahankan masyarakat, merupakan identitas kultural dalam bentuk norma, etika, kepercayaan, adat-istiadat dan aturan khusus, sehingga dapat bertahan secara terus-menerus (Sibarani, 2012: 112-113).

Keberadaan local genius dalam komunitas masyarakat relatif beragam pada setiap suku-bangsa. Dalam masyarakat kita, local genius dapat ditemui dalam nyanyian, pepatah, sasanti, petuah, semboyan, dan kitab-kitab kuno yang melekat dalam perilaku sehari-hari. Local genius ini pula yang kita

Received: 31 Agustus 2015, Revision: 20 September 2015, Accepted: 23 Desember 2015

Print ISSN: 0215-8175; Online ISSN: 2303-2499. Copyright@2015. Published by Pusat Penerbitan Universitas (P2U) LPPM Unisba Terakreditasi SK Kemendikbud, No.040/P/2014, berlaku 18-02-2014 s.d 18-02-2019 
angkat menjadi bagian dari karakter bangsa, dan menjadi spirit dari setiap pembuatan dan aplikasi kebijakan di masyarakat, sehingga seluruh kebijakan yang dimiliki pemerintah diterjemahkan dan diimplementasikan dengan lebih membumi dalam kehidupan sehari-hari.

Local genius dengan demikian menjadi unsur penting dalam membumikan dan melibatkan seluruh unsur masyarakat dalam proses pembuatan dan implementasi kebijakan pemerintah. Namun, corak budaya patriarki dalam praktiknya di Indonesia ternyata justru dianggap menghambat partisipasi, khususnya bagi perempuan dalam akses kebijakan dan pembangunan sehingga terjadi ketidaksetaraan gender. Ketidaksetaraan akses tersebut, antara lain disebabkan dominasi pelaksanaan nilai patriarki.

Asumsi tersebut lahir dari realitas bahwa meskipun perempuan merupakan bagian berbagai aktivitas local genius, dan agen utama dari transformasi local genius dari generasi ke generasi, dan perempuan menjadi pelaksana dan agen local genius, tidak menjamin bahwa nilai kearifan yang dilaksanakannya menjunjung kesetaraan dan melawan budaya patriarki.

Pentingnya sinergi antara local genius dengan kebijakan pengarusutamaan gender merupakan strategi untuk mencapai keadilan dan kesetaraan gender melalui kebijakan dan program yang memerhatikan pengalaman, aspirasi, kebutuhan dan permasalahan perempuan dan laki-laki ke dalam perencanaan, pelaksanaan, monitoring dan evaluasi, seluruh kebijakan dan program di berbagai bidang kehidupan dan pembangunan.

Sinergitas antara local genius dan pengarusutamaan gender ditujukan agar semua program pembangunan dapat dilaksanakan dengan mempertimbangkan kesempatan dan akses perempuan terhadap program pembangunan, dengan adanya kendali dan manfaat untuk perempuan.

Untuk pencapaian hal tersebut dilakukan dengan strategi pengarusutamaan pencapaian MDGs dalam Rencana Pembangunan Jangka Menengah Nasional (RPJMN) Tahun 20102014 , dengan penetapan program/kegiatan, sasaran, indikator, dan target terukur, serta jaminan penyediaan sumber pembiayaan. Untuk Indonesia, arah pencapaian pengarustamaan gender masih sangat terkait dengan program peningkatan pemberdayaan perempuan. Perempuan memegang peranan yang sangat strategis dalam pencapaian keadilan dan kesetaraan gender.

Pengarusutamaan gender telah diberlakukan secara nasional, pada kenyataannya masih jauh dari yang diharapkan. Menurut Laporan Pembangunan Manusia ${ }^{1} 2007 / 2008$ yang dipublikasikan oleh UNDP, nilai GDI Indonesia, yaitu 0,721 harus diperbandingkan dengan nilai HDI-nya 0,728. Nilai GDI Indonesia adalah 99,1\% dari nilai HDI-nya. Dari 156 negara yang memiliki nilai HDI dan GDI, 79 negara mempunyai rasio yang lebih baik daripada Indonesia (UNDP, 16 Pebruari 2008). Sedangkan menurut laporan yang dipublikasikan oleh Badan Koordinasi Keluarga Berencana Nasional (BKKBN), bahwa pada tahun 2005 Provinsi Sumatera Utara berada pada peringkat ke-18 dari 33 provinsi yang ada di Indonesia (BKKBN, diakses pada tanggal 16 Oktober 2014).

Menurut data yang diperoleh dari Badan Kepegawaian Daerah (BKD) Provinsi Sumatera Utara mengenai rekapitulasi jumlah Pegawai Negeri Sipil (PNS) di lingkungan pemerintahan Provinsi Sumatera Utara per September 2007, jumlah PNS pria jauh lebih besar dibandingkan dengan jumlah PNS wanita, yaitu sebanyak 7.513 orang PNS pria berbanding 3.402 orang PNS wanita. Dari data tersebut juga diperoleh bahwa jumlah wanita yang termasuk dalam pejabat Eselon I dan II hanya berjumlah 4 (empat) orang (Badan Kepegawaian Daerah Provinsi Sumatera Utara, Penelitian Lapangan 2008).

Hal ini menunjukkan dikotomi antara budaya patriarki yang berasal dari masyarakat dan sudah tertanam kuat dalam kehidupan masyarakat, dengan usaha pemerintah untuk percepatan pembangunan dengan melibatkan seluruh elemen masyarakat dengan penerapan pengarusutamaan gender akhirnya terlihat menjadi bertolak belakang dan justru menjadi salah satu permasalahan pembangunan.

\section{"Local Genius" yang Berpengaru- sutamaan Gender}

Sejarah perbedaan gender (gender differences) manusia jenis laki-laki dan perempuan terjadi melalui proses yang sangat panjang. Oleh karena itu, terbentuknya perbedaan-perbedaan gender dikarenakan oleh banyak hal, diantaranya dibentuk, disosialisasikan, diperkuat, bahkan dikonstruksikan secara sosial atau kultural, melalui proses pengenalan tentang agama 
dan kepercayaan, maupun kenegaraan (Fakih, 1999: 90). Dalam masyarakat Karo dan Nias Selatan, proses sosialisasi gender sudah diperkenalkan kepada anak sejak kecil, diarahkan dan dibedakan sesuai dengan keberadaan status kewanitaan dan kelelakian. Anak laki-laki dalam masyarakat Karo dan Nias Selatan mempunyai fungsi sosial yang sangat luas sebagai pelanjut silsilah keluarga, sebagai penerima harta warisan, dan sebagai penentu pengambilan keputusan.

Menggali nilai-nilai local genius yang merupakan cultural identity dan unsur budaya daerah potensial yang telah teruji kemampuannya untuk bertahan sampai sekarang, bila dikaitkan dengan konsep gender, sesungguhnya di tiap daerah memiliki local genius yang dapat dikembangkan untuk mendorong kesetaraan gender sekaligus pelestarian budaya daerah. Penelitian yang dilakukan di Nias Selatan dan Karo menghasilkan beberapa local genius yang mengandung nilai-nilai pengarusutamaan gender antara lain:

\section{Gender dan Ritual dalam Masyarakat Karo dan Nias Selatan}

Pada Masyarakat Karo, kegiatan mengaktifkan kebudayaan dalam masyarakat tradisional, khususnya di Tanah Karo, sangat kental diwujudkan dalam pelaksanaan berbagai ritual upacara tradisional, yang menjadi sarana sosialisasi bagi kebudayaan dan sudah menjadi turun-temurun. Ritual upacara tradisional merupakan salah satu manifestasi dari kreasi manusia sebagai makhluk sosial. Untuk menggali local genius dalam masyarakat tradisional Karo dapat dilihat dari bagaimana ritual upacara tradisional dilaksanakan yang terkait dengan siklus hidup (kelahiran-perkawinan-kematian).

Siklus hidup dalam masyarakat Karo yang mengandung nilai pengarusutamaan gender dapat dilihat dari ritual upacara adat dalam pembuatan rumah tradisional adat Karo, di mana dalam pembuatannya peran gender yang seimbang dimulai pada saat mendirikan rumah, di mana pada bagian awal terlebih dahulu dilakukan permufakatan (persada arih) antara raja bakal pemilik rumah (bena kayu) dengan istri. Kemudian yang bersangkutan menanyakan kesediaan pihak keluarga pemberi istri (kalimbubu) untuk tinggal bersama, selanjutnya memberitahukan pihak keluarga penerima istri (anak beru), dan diakhiri dengan memanggil biak senina, sehingga lengkap empat atau delapan keluarga yang akan mendiami rumah tradisional adat Karo. Dapat dilihat pada saat mencapai permufakatan, gender perempuan dalam hal ini istri dari calon pemilik rumah menempatkan diri sebagai penentu kebijakan.

Selanjutnya, peran gender dalam terutama kaum perempuan juga berlanjut pada bagian-bagian yang lain. Salah satu contoh adalah di saat upacara menyediakan tanah untuk dapur (ngelengkapi taneh dapur), Pertama-tama, guru memilih tanah yang sesuai yaitu yang bebas dari penyakit serta serasi menurut penglihatannya. Tanah diangkat dengan sejenis keranjang (beha) yang biasa dipakai untuk upacara adat, kemudian tanah tersebut diisi dengan ramuan (rudang sinikas gelar). Untuk membawa atau menjunjung tanah ini biasanya dipilih dari pihak penerima gadis (anak beru) yang punya rumah, seorang perempuan yang masih gadis dan masih lengkap keluarganya (sangkep).

Pelaksanaan upacara pertama adalah menyiapkan ramuan dan sesajen di teras rumah (ture), kemudian dibawa ke dalam keranjang (beha), dijunjung oleh seorang perempuan yang memakai tutup kepala (tudung nisarintang) dan kain (abit) yang dipakai dari pinggang sampai kaki betis (urus teha atau julu). Dengan berjalan di depan, sang guru membawa sesajen dan mencipratkannya kepada seluruh penghuni rumah dan kemudian menuju dapur. Tanah yang dibawa dimasukkan ke semua dapur yang ada di dalam rumah (rudang-rudang simelias gelar).

Mengenai hal ini dijelaskan juga oleh Malem Bangun:

"Kalau buat rumah dulu, perempuan ikut juga ambil bagian, misalnya anak perempuan itu tugasnya buat sajen, ada keranjangnya juga, nanti ada upacara adatnya, mereka juga yang ikut bawa dan ada pakaian khususnya."

Ritual mengisi peralatan dapur juga melibatkan perempuan di mana para gadis atau perempuan yang masih perawan dan lengkap keluarganya (sangkep) akan membawa ranting kayu bakar sambil bersenandung yang disebut eralep-alep. Kemudian, salah seorang dari pihak pemberi istri yang sudah memiliki keturunan (si utang rido) bertugas memasang tungku. Bila seorang mantu atau seseorang yang berposisi sebagai menantu (anak dari saudara perempuan) yang disebut bere-bere memasuki rumah baru (mengket rumah mbaru), maka mertua atau paman pihak penerima istrinya (kalimbubu) yang akan memasang tungku. Dalam upacara tersebut diadakan tanya jawab ritual (perasiken), 
tentang siapa yang akan memasang tungku dan apakah tungku yang akan dipasang sudah tersedia atau belum.

Berdasarkan paparan di atas dapat dijelaskan bahwa pada semua bagian dalam kehidupan di rumah Karo, mulai dari awal pembuatan rumah sampai pemakaian ruang-ruang, peranan gender perempuan menempati posisi sentral, terutama dalam ritual atau upacara adat.

Berbeda dengan masyarakat Karo, masyarakat tradisional Nias yang berkastakasta (12 tingkatan kasta) lebih banyak memiliki mitos-mitos dalam berbagai aspek kehidupannya.

Berdasarkan sistem kasta, tingkatan kasta yang tertinggi adalah balugu dan untuk mencapai tingkatan ini seseorang harus mampu melakukan pesta besar dengan mengundang ribuan orang dan menyembelih ribuan ekor ternak babi selama berhari-hari. Ritual upacara adat hingga saat ini masih menjadi kewajiban yang harus dijalankan oleh keturunan bangsawan saja, sedangkan masyarakat biasa tidak memiliki banyak ritual dalam siklus hidupnya. Dalam hal rumah adat, masyarakat Nias juga memiliki beberapa jenis rumah yang dibedakan berdasarkan daerah dan juga berdasarkan kasta.

Bagi kaum bangsawan Nias, pembuatan rumah besar (omo nifolasara) adalah bagian dari penyempurnaan untuk mendapatkan gelar kebangsawanan tertinggi setelah melewati 7 tingkat ritual pengangkatan batu yang disusun di halaman rumah. Prosesi ritual pembangunan rumah adat Nias dimulai dengan pengangkatan seluruh kayu besar ke desa. Pada prosesi ini, peran perempuan ialah menarikan tarian adat yang biasa disebut tarian maena dengan mengenakan pakaian sejenis kemben yang biasa dipakai perempuan Jawa.

Ritual tarian ini bertujuan menyambut para lelaki yang menarik kayu-kayu besar agar bersemangat dan dapat menariknya hingga ke desa yang biasanya letaknnya di atas bukit.

Pernyataan ini diperkuat oleh pernyataan bangsawan Bawomataluo:

"Itulah dulu salah satu kecerdasan raja Nias di Bawomataluo ini. Itukan kayu-kayunya dibawa jauh dari Pulau Batu, untuk bisa naik ke atas sini, ditarik rame-rame sama orang kampung. Udah sampai di bawah kampung ini, Raja menyuruh perempuan-perempuan menyambut mereka - laki-laki itu dengan tari-tarian. Disuruh perempuan-perempuan itu pakai baju yang kayak kemben Jawa se- karang ini, biar laki-laki itu semangat lagi narik kayu sampai ke atas sini. Kan malu laki-lakinya kalau sampai nggak terangkat kayu itu ditengok sama perempuan."

Pengesahan Omo Sebua ditandai dengan ditutupnya atap bagian tertinggi dari rumah yang mengorbankan nyawa arsitek yang merancang rumah tersebut. Berdasarkan prosesi yang ada, peran perempuan dalam masyarakat Nias dalam pembuatan rumah adat tidak memiliki peran sentral dan hanya sebagai pelengkap saja.

\section{Perspektif Gender dalam Ritual Adat Pernikahan Karo dan Nias Selatan}

Dalam kebudayaan tinggi (high culture) Karo, seorang anak perempuan yang dinikahi oleh seorang laki-laki akan menciptakan suatu aturan main tersendiri mengenai posisi dari kedua belah pihak keluarga yang bersangkutan. Pihak keluarga dari seorang anak perempuan yang dinikahi oleh seorang laki-laki akan memiliki posisi istimewa terhadap pihak keluarga laki-laki tersebut secara keseluruhan. Posisi ini dalam bahasa Karo disebut dengan istilah "kalimbubu." Sarjani menjelaskan:

"Lebih lanjut posisi istimewa dan "lebih tinggi" dari kalimbubu ini juga semakin dipertegas dengan pensinonimannya dengan istilah debata trida, yaitu "Tuhan-tuhan yang tampak". Penggunaan istilah debata trida ini menunjukkan bagaimana posisi absolut dari pihak keluarga perempuan terhadap pihak keluarga laki-laki yang diibaratkan sebagai manifestasi dari Tuhan. Makna sebagai tuhan-tuhan yang tampak ini dijelaskan dengan implementasi berupa kepatuhan dan ketaatan yang harus dipenuhi dan dilakukan oleh keluarga pihak laki-laki terhadap seluruh hal yang diajukan oleh pihak keluarga perempuan."

Melalui konsep mengenai kalimbubu, maka seorang anak perempuan dalam latar kultural Karo akan memiliki posisi yang sangat penting ketika ia dinikahi oleh seorang laki-laki, untuk mengangkat kedudukan pihak keluarganya terhadap pihak keluarga laki-laki, dan memiliki peran yang dalam hal perluasan jaringan kekerabatan, yang diimplementasikan dengan bentuk perkawinan.

Pada sisi kontrol sosial sendiri, konsep kalimbubu ini dapat juga menunjukkan bagaimana kebudayaan Karo berusaha mengonstruksikan secara ideal bagaimana pengawasan dan kontrol mutlak yang dimiliki oleh pihak keluarga perempuan agar dapat terus-menerus menjaga, melindungi, dan mengawasi keadaan anak perempuannya yang telah dinikahi oleh seorang laki-laki dari keluarga lain. Pada sisi feminisme-nya 
sendiri, latar kultural ini dapat dikatakan telah menjamin eksistensi kaum perempuan secara ideal dalam kehidupan berumah tangga.

Masyarakat Nias memiliki acara sebelum berlangsungnya perkawinan yang biasa disebut Mamaigi Niha adalah pihak laki-laki mengutus seseorang sebagai perantara yang disebut sio, fame'e huhuo atau meminang adalah pernyataan kehendak dari satu pihak keluarga laki-laki kepada pihak keluarga perempuan untuk maksud mengadakan ikatan perkawinan. Fatunanga atau pertunangan adalah hubungan hukum yang dilakukan antara orangtua pihak laki-laki dengan orangtua wanita untuk mengikat tali perkawinan anak-anak mereka dengan jalan peminangan terlebih dahulu. Fanura ana'a adalah pelaksanaan pemberian jujur yang telah dirundingkan pada waktu fatunanga. Jujur adalah uang yang diminta pihak keluarga perempuan sebagai biaya pernikahan.

Acara saat berlangsungnya perkawinan atau faekhu walówa, yaitu pada acara pelaksanaan perkawinan yang sangat terpenting adalah bahwa perkawinan tersebut sah menurut hukum yaitu: upacara hada/ adat, upacara agama/pemberkatan nikah, pencatatan di kantor catatan sipil. Acara setelah terjadinya perkawinan antara lain mame'e gỏ adalah pihak keluarga perempuan mengantar makanan kepada anaknya perempuan, mameli nukha adalah acara dimana pihak laki-laki datang ke rumah perempuan dengan maksud mengambil seluruh barang dan pakaian serta hadiah perkawinan yang menjadi milik perempuan.

Dampak perkawinan jujur bagi masyarakat adat Nias yaitu dampak positif antara lain, kekerabatan fambambatỏsa, fasitengabóỏ semakin terjalin, dengan jujur yang tinggi jarang terjadinya perceraian, jujur atau bówó yang tinggi memberi pengertian bahwa anak perempuan tersebut perempuan yang terhormat, memberi pelajaran bagi anak-anak muda bahwa perkawinan tidak gampang betul-betul butuh persiapan yang matang sebelum melakukan perkawinan. Karena, akibat sosial yang akan terjadi apabila pihak laki-laki tidak mampu membayar bówỏ atau jujur yang sudah dijanjikan, pihak keluarga perempuan bisa menghilangkan nyawa salah satu dari pihak keluarga laki-laki, tidak ada kebahagiaan, memberikan kesan buruk terhadap perkawinan jujur.

Namun, pada sisi lain perempuan pada akhirnya sama sekali tidak diperhitungkan, selain dalam hal pernikahan. Karena konsep bowo menjadikan perempuan Nias sebagai aset yang harus berpindah, dari pihak perempuan kepada pihak laki-laki sehingga kemudian seluruh biaya yang timbul dalam pernikahan dikalkulasikan. Eva Chris Susanti Duha mengatakan:

"Tidak usah heran jika pernikahan di Nias sangat mahal. Penghitungan biaya yang harus dikeluarkan kepada struktur keluarga perempuan saja bisa mencapai enam tingkatan posisi, di mana masing-masing memiliki porsi tersendiri, meski secara umum bervariasi di seluruh Pulau Nias. Belum lagi biaya yang harus "dibayarkan" kepada para tokoh sosial dan tokoh agama. Biaya dalam pernikahan itulah yang kemudian menjadi "nasib buruk" perempuan di Pulau Nias. Dan, biaya-biaya itulah yang menentukan lamanya penderitaannya. Biaya yang umumnya berasal dari utang itu bisa kemudian lunas setahun, dua tahun, lima tahun kemudian bahkan mungkin sampai sampai anak cucunya."

Arianto Simon Fau menambahkan:

\begin{abstract}
"Jadinya sebagian besar anak laki-laki yang baru menikah akan tinggal bersama orangtua dalam waktu yang tidak ditentukan. Jika pasangan ini sudah mampu membayar utang sebagai akibat pernikahan, barulah mereka berupaya menempati rumah secara terpisah. Suami adalah penanggung jawab kebutuhan ekonomi keluarga, sedangkan istri mengerjakan pekerjaan-pekerjaan rumah tangga. Ironisnya, masih banyak suami bermalas-malasan bekerja, bahkan mempunyai kebiasaan buruk, yaitu mabuk-mabukan. Akibatnya, istri harus bekerja keras menyadap karet dan mencari daun ubi jalar untuk makanan ternak mereka."
\end{abstract}

\section{Peran Perempuan dalam Bidang Pertanian dan Ekonomi}

Masyarakat Karo adalah masyarakat agraris. Pusat perekonomian masyarakat Karo berasal dari hasil pertaniannya berupa bahan pokok, buah-buahan dan sayuran. Dalam hal pertanian, perempuan dalam masyarakat Karo memiliki peran sentral yang sangat penting. Karena perempuanlah yang terlibat penuh dalam siklus bertani, mulai dari mengelola tanah, menanam, menjaga tanah dari hama, hingga menjual hasil pertanian ke pasar. Bahkan, ketika perempuan mengerjakan tanah pertanian, kaum lelaki hanya duduk di kedai kopi atau tuak. Pdt. Jennie Keliat menjelaskan:

"Semua kegiatan yang berhubungan dengan kepentingan rumah tangga dan reproduksi dilimpahkan ke perempuan. Hal ini sering terlihat dari besarnya volume kerja yang harus diselesaikan oleh ibu rumah tangga setiap harinya di dalam rumah. Perempuan harus menyiapkan makanan untuk pagi dan siang hari yang akan dibawa ke ladang, mengurus anak-anak yang akan berangkat sekolah. Kalau masih ada yang balita, anakn- 
ya akan di bawa ke ladang bersama si ibu. Kemudian si Ibu juga masih harus memberi makan ternak dan menyiapkan peralatan apa yang dibutuhkan untuk berladang."

Dominasi wanita di sektor produktif merupakan implikasi dari adat rebu terhadap kelompok aron. Kaum wanita juga dapat menentukan dan mendistribusikan jenis pekerjaan yang harus dilaksanakan sehubungan dengan aktivitas pertanian mereka pada periode tertentu. Partisipasi pria dalam aktivitas pertanian hanya terlihat pada tahap penyemprotan tanaman dan pada masa panen. Dalam aktivitas mencangkul lahan pertanian, menanam dan menyiangi tanaman lebih banyak dilakukan oleh kaum wanita.

Salah satu tradisi ono niha (orang Nias) yang masih hidup dan tetap dipertahankan sampai sekarang yaitu bolanafo. Bolanafo, terdiri dari dua suku kata yaitu bola dan afo. Bola identik dengan pengertian tempat, sedangkan afo adalah lima ramuan dari tawuo (daun sirih), betua (kapur), gambe (daun gambir), bago (tembakau), dan fino (buah pinang).

Kelima unsur ramuan afo dihimpun dan disusun dengan rapi di dalam wadah (bola), yang secara utuh disebut bolanafo (tempat sirih). Bahan baku anyaman bolanafo terbuat dari sejenis rumput rawa-rawa Keleömö (Eleocharis dulcis) yang dikeringkan dan dipipihkan, lalu diberi pewarna dan dianyam. Bagian dalamnya terbuat dari daun tanaman pandan berduri, sinasa. Lingkaran bagian mulut anyaman bolanafo dibalut kain berwarna merah. Motif setiap ornamen bolanafo sangat unik dan indah dengan dominasi warna merah berkombinasi warna-warna alam yang cerah dengan menggunakan pewarna berbahan baku alami, yang diambil dari buah, akar-akar pohon, dan dedaunan misalnya buah pohon sianuza digunakan untuk pewarna merah. Arianto Simon Fau mennjelaskan:

\begin{abstract}
"Menganyam wadah atau Bolanafo dilakukan oleh pengrajin tradisional Nias yang umumnya adalah para perempuan dan ibu. Pengrajin tradisionil bolanafo masih terdapat di desa-desa pedalaman Nias dalam jumlah sedikit dan mereka yang bertalenta itu merupakan ibuibu. Makan sirih merupakan kebiasaan orang Nias. Selain untuk ramuan kunyahan, sirih memiliki arti khusus dalam tradisi Nias. Fame'e afo atau menyuguhkan sirih adalah sebuah tradisi penyambutan dan penghormatan tamu."
\end{abstract}

Pembuatan bolanafo ini pada awalnya karena kebiasaan masyarakat Nias dimana para ina (ibu) meramu sirih lalu menata ke dalam bolanafo dan disuguhkan. Cara menyuguhkan kepada tamu juga dengan aturan tertentu dengan bersujud dan biasanya diawali dengan memberi salam penghormatan yang disebut Fangowai. Makan sirih mempunyai makna simbolik yang dalam. Penyuguhan dan makan sirih bersama disimbolkan sebagai upaya menyatukan pemikiran yang berbeda, merajut perpecahan dan membangun harapan bersama. Oleh sebab itu, makan sirih merupakan aktivitas awal dalam setiap pertemuan adat, keluarga, dan acara besar masyarakat Nias. Bila semua dapat duduk bersama makan sirih, maka dapatlah dikatakan bahwa sudah saling menghormati, menerima dan memahami, sehingga pembicaraan atau perhelatan yang menjadi inti pertemuan bisa dilakukan. Ini sebuah kearifan yang sangat bernilai.

\section{Perempuan dan Pengobatan Tra- disional Masyarakat Karo dan Nias Selatan}

Oukup merupakan pemandian sauna tradisional khas suku Karo yang memanfaatkan berbagai jenis tumbuhan sebagai ramuannya. Mandi sauna ini bermanfaat untuk kesehatan para ibu baru melahirkan, serta dipercaya dapat mengobati berbagai jenis penyakit; seperti penyakit gula darah, rheumatik, asam urat, dan lain sebagainya.

Secara umum, metode oukup sangat mirip dengan mandi sauna yang banyak terdapat di rumah kecantikan. Namun hal yang membedakannya adalah oukup menggunakan ramuan khas Karo untuk menghasilkan aroma yang menyegarkan yang kemudian berkhasiat untuk penyembuhan penyakit. Untuk membuat ramuan oukup, biasanya yang mengerjakannya adalah perempuan, seperti yang dijelaskan oleh Robert Perangin-Angin:

"Untuk rempah-rempah oukuup, perempuan yang biasa membuat ramuan obat-obatannya. Karena oukup sering digunakan untuk pemulihan ibu-ibu yang baru saja selesai melahirkan."

Selain oukup, masyarakat Karo memiliki tradisi menanam berbagai jenis tanaman pangan, sayur, dan palawija di pekarangan rumah masing-masing masyarakat. Apotik hidup ini juga dikelola oleh perempuan Karo sebagai bahan-bahan untuk persiapan melahirkan bagi perempuan dan pengobatan bagi keluarga yang sakit.

Masyarakat Nias dalam hal pengobatan tradisionalnya, memiliki beberapa jenis ramuan, seperti binu mba'e = sarang semut (Myrmecodia pendans) mempunyai akar yang menempel pada pohon inang. Dalam 
pengobatan tradisional Nias, binu mba'e dimanfaatkan sebagai untuk mengurangi bengkak. Binu mba'e ditumbuk halus kemudian dioleskan pada bagian yang sakit. Juga sebagai obat buru (perut kembung dan dingin menjalari ke seluruh tubuh). Tanaman khas duria ulöndra/ garoto (Sirsak = Annona muricata) manjur sebagai obat kanker. Dalam pengobatan tradisional Nias, yang lebih banyak dimanfaatkan adalah daunnya yakni untuk mengobati pendarahan terus-menerus "tika late" yang biasanya diderita oleh kaum perempuan (menurut para dukun di Nias).

\section{Perempuan dan Ruang Publik dalam Masyarakat Karo dan Nias Selatan}

Walau tidak memiliki hak bicara dalam pertemuan, setiap kali di akhir acara perempuan selalu ditanyai persetujuannya, dimana secara simbolis pihak laki-laki akan membalikkan badan menghadap ke arah kelompok perempuan dan bertanya, apakah semuanya setuju dengan hasil pembahasan yang telah mereka dengar dalam pertemuan tersebut, kemudian kelompok perempuan serentak menjawab "ya". Seperti yang dijelaskan oleh Sarjani:

\begin{abstract}
"Kalau dalam pertemuan, dari dahulu perempuan memang tidak punya hak bicara, hanya laki-laki saja yang bicara. Tapi, kalau ada permasalahan yang hanya diketahui oleh perempuan, ya akan ditanyakan ke perempuan bersangkutan yang mengetahuinya. Perempuan kalau pertemuan begitu, biasanya duduk satu kelompok di belakang barisan laki-laki. Nanti kalau sudah di akhir pertemuan, perempuan ditanyai apakah mereka setuju semuanya kan, dan serentak nanti perempuannya menjawab 'ya'. Itu sebagai simbolis bahwa perempuan tetap dibutuhkan persetujuannya dalam hal apapun."
\end{abstract}

Berdasarkan wawancara dengan tokoh adat Nias, perempuan dianggap memiliki kedudukan istimewa perempuan dalam budaya Nias. Dalam adat, perempuan sangat dijunjung tinggi. Misalnya perempuan itu memberi nasehat, dan perempuan mengadakan "fangowai" (penghormatan) terhadap tamu."

Jadi, dalam beberapa hal, misalnya dalam pesta perkawinan, perempuanlah yang pertama menyambut tamu dan mereka juga yang berhak memberi nasihat pada pengantin perempuan menjelang hari pernikahannya. Jika ditinjau lebih dalam lagi, sebenarnya perempuan memiliki kuasa-kuasa tertentu yang tidak dapat digantikan oleh laki-laki, seperti halnya dalam pesta perkawinan, seperti yang diungkapkan Falakhimi Zamili:
"Meskipun suara perempuan tidak begitu dinomorsatukan akan tetapi didengarkan juga, "Perempuan juga tidak bisa banyak bicara dalam adat tetapi suara ibu itu biasanya sungguh didengar." Artinya, suara ibu itu sangat berpengaruh, khusus bagi anak-anaknya sendiri. Mereka mendengarkan suara ibu karena kasih ibu itu sendiri, meskipun mereka lebih sering taat pada Ayah, karena figur otoriter yang menghukum bila tidak ditaati. Akan tetapi, jika seorang anak sudah mandiri dan tidak takut pada figur ayah, mereka akan cenderung lebih menaati Ibu daripada Ayah. Peranan perempuan dalam hal itu adalah sebagai seorang ibu yang mempunyai senjata kelembutan hati."

Ditambahkan oleh Teruna Wau:

"Sejak dahulu, perempuan Nias itu sangat dihargai, kalau di jalan kita laki-laki dan perempuan berpapasan di jalan, dulu itu laki-laki harus menyingkir dulu, dan tidak boleh melihat perempuan yang lewat itu..."

Sedangkan dalam pertemuanpertemuan sosial dan kemasyarakatan, perempuan Nias umumnya tidak memiliki peran apa-apa, kecuali memasak dan melayani pelaksanaan pertemuan tersebut. Perempuan Nias umumnya tidak akan menjawab apa-apa meskipun ditanyakan karena semua keputusan ada di tangan lakilaki (suaminya).

"Kalau perempuan sini (Nias.red) tidak pernah ikut dalam rapat desa. Mereka juga tidak boleh naik ke balai desa. Cuma laki-laki saja yang ikut dalam rapat adat."

\section{Implementasi "Local Genius" dengan Kebijakan Pemerintah yang Berbasis pada Pengarusutamaan Gender}

Berdasarkan Rencana Kerja Pembangunan Daerah Kabupaten (RPJMD) Kabupaten Karo tahun 2015, pada bidang ekonomi dan pertanian, dimana perempuan memiliki peran dominan, pemerintah Kabupaten Karo masih belum maksimal dalam memasukkan nilai-nilai local genius yang berpengarusutamaan gender.

Dalam RPJMD Kabupaten Karo, untuk bidang pertanian terdapat rencana program 'Pemanfaatan Pekarangan untuk Pengembangan Pangan'. Program tersebut sejalan dengan nilai local genius Karo di masa lampau, dimana masyarakat Karo dahulu memiliki tradisi untuk menanam berbagai macam tanaman obat-obatan dan pangan di pekarangan rumah yang dilakukan oleh perempuan. Pemanfaatan pekarangan rumah ini dan memenuhi kebutuhan sehari-hari dan yang paling penting adalah persiapan untuk melahirkan kaum perempuan. Seperti penjelasan dari Kepala Dinas Kesehatan, Robert Perangin-Angin: 
"Kalau untuk nilai local genius yang kami angkat jadi program di dinas kesehatan saat ini adalah pengembangan apotik hidup yang ukurannya paling kecil sepuluh meteran. Kalau dahulu itu untuk tanaman ibu-ibu, ada banyak tanaman obat-obatan, jadi ketika melahirkan sang Ibu, tinggal dipetik tanamanannya sama dukun beranak. Nah, sekarang program ini dihidupkan kembali dalam rangka kesehatan keluarga dan ketahanan panga juga, karena pekarangan warga masih banyak yang lumayan luas untuk ditanami."

Oukup yang juga merupakan pengobatan khas Karo saat ini sudah berkembang begitu pesat, bahkan di kota Medan. Oukup dikomersilkan dan menjadi salah satu mata pencaharian khas warga Karo. Namun, pemerintah belum menjadikan pengembangan oukup sebagai program untuk bidang kesehatan maupun pariwisata.

Ritual-ritual dalam masyarakat Karo hingga saat ini masih terjaga dan dijalankan oleh warga Karo. Salah satu ritual yang sudah masuk menjadi program pemerintah Kabupaten Karo adalah Pesta Tahun, dimana seluruh warga Karo dimanapun berada, biasanya pada hari Pesta Tahun akan pulang ke Karo untuk merayakannya.

Dalam perayaan Pesta Tahun, dahulu warga bergotong royong dari segi pendanaan dan tenaga untuk membuat makanan khas Karo, dan pada hari tersebut, siapapun yang datang ke daerah tempat Pesta Tahun berlangsung boleh makan gratis sepuasnya. Dalam Pesta Tahun sendiri pembagian peran antara laki-laki dan perempuan seimbang, dimana laki-laki dan perempuan bekerja sama dalam memasak makanan dan mempersiapkan Pesta Tahun. Ritual Pesta Tahun ini menjadi program pemerintah untuk menarik wisatawan datang ke Tanah Karo.

Berdasarkan hasil FGD, diketahui juga bahwa Pesta Tahun ini sudah mulai dibuat pada tingkat kecamatan dan kelurahan, dimana semua warga di tempat diadakan Pesta Tahun terlibat, dan pemerintah memberikan bantuan dana untuk program tersebut.

Dinamika sosial dan peran dominan perempuan Karo dalam bidang ekonomi terkait pengelolaan lahan pertanian, bila dilihat dalam lembaran RPJMD, seluruh program pada bidang pertanian akan langsung dirasakan oleh kaum perempuan seperti program: pemberian bibit, subsidi pupuk pertanian, dan berbagai penyuluhan dalam hal untuk peningkatan mutu dan hasil pertanian.

Begitu juga dengan keberadaan di ruang publik, pada saat ini pemerintah mendorong perempuan untuk bisa masuk dalam pemerintahan, walaupun belum secara kuantitas jumlah pegawai laki-laki dan perempuan pada bidang pemerintahan. Pegawai Negeri Sipil (PNS) perempuan pada jajaran tertinggi pemerintah Kabupaten Karo masih empat orang saja, sedangkan untuk bidang legislatif terdapat tujuh orang anggota DRPD perempuan di Kabupaten Karo.

Berdasarkan hasil wawancara dengan anggota DPRD Herty Delima Purba, dalam hal pekerjaannya sebagai anggota legislatif: "Memang sebagai perempuan, saya memi-
liki usaha lebih untuk bisa menjadi anggota
DPRD. Setelah kami duduk di sana, kami para
perempuan tidak mengalami banyak kenda-
la, tinggal bagaimana kami sebagai perem-
puan yang ada di sana tahu harus bagaimana
memperjuangkan kebutuhan-kebutuhan kon-
stituen yang telah memilih kami. Walaupun
kami baru saja dilantik sebagai anggota de-
wan, kami sudah persiapan untuk membentuk
kaukus politik perempuan untuk peningkatan
kuantitas dan kualitas kapasitas perempuan."

Pembagian peran gender dalam rumah tangga di berbagai budaya patrilineal, kebanyakan kaum perempuannya yang selalu dihadapkan dengan pekerjaan memasak, mencuci, mengasuh anak, membersihkan rumah. Sementara kaum pria lebih banyak mengerjakan jenis pekerjaan yang membutuhkan kekuatan fisik; memperbaiki rumah, memelihara ternak. Dari hasil pengamatan wawancara dan FGD, perempuan Nias secara keseluruhan tidak memiliki peran publik, hanya domestik semata. Sedangkan untuk berbagai ritual adat, seperti yang telah dijelaskan sebelumnya, kasta bangsawan yang memiliki peran sentral untuk ritual-ritual tersebut, sehingga kedudukan kaum perempuan cenderung diabaikan dan dilupakan begitu saja hanya pada sektor domestik saja. Namun dalam masyarakat modern Nias, jika kaum perempuan mau berusaha kaum, laki-laki Nias juga tidak membatasi gerak perempuan dalam ruang publik. Hanya saja, terkait dengan kondisi masyarakat Nias yang selama ini tingkat pendidikannya masih sangat rendah baik laki-laki maupun perempuan, maka kaum perempuan juga masih belum banyak yang memiliki kesadaran untuk maju dan berperan aktif dalam ruang publik.

Hal ini juga dinyatakan oleh anggota DPRD Nias Selatan, Yuslinar Bidaya:

"Sebenarnya kalau saya tidak mengalami hambatan untuk masuk dalam dunia politik, malah suami saya juga aktif membantu saya. Hanya saja, banyak perempuan Nias yang masih belum menyadari dan mau ber- 
partisipasi untuk aktif dalam di ruang publik, dan mungkin juga terkait dengan stereotype dari masa lalu ya, seperti perempuan Nias itu pemalas, khususnya perempuan dari Kepulauan Batu itu sangat pemalas. Nah, saya mencoba untuk mendobrak itu, karena saya dari Kepulauan Batu, tapi saya tidak malas dan bisa mengerjakan banyak hal, salah satunya dengan menjadi anggota dewan..."

Budaya Nias yang tidak memiliki budaya tulisan tetapi budaya lisan, menyebabkan pola pendidikan diterapkan dalam bentuk berbagai cerita-cerita yang menjadi mitos.

Dalam masyarakat Nias, perempuan tidak memiliki cerita-cerita yang istimewa, atau tidak memiliki cerita mitos yang menggambarkan bagaimana perempuan memiliki peran yang hebat atau tidak biasa dalam masyarakat. Hanya ada satu mitos yang menceritakan tentang perempuan bernama 'Inada Silowo' yang dalam cerita dianggap sebagai perempuan sakti. Namun sosok perempuan sakti Inada Silowo juga tidak bisa dijabarkan apakah ia memiliki peran yang baik atau jahat terkait dengan kesaktiannya. Inada Silowo diceritakan masyarakat sebagai perempuan yang memiliki kemampuan berpindah-pindah saja. Hal ini diungkapkan oleh Eva Chris Susanti Duha:

"Kalau di Nias, tentang perempuan tidak ada
satu pun tokoh perempuan yang menonjol.
Hanya ada tentang Inada Silowo, cerita dari
zaman dahulu, katanya dia perempuan sakti
yang bisa berpindah-pindah. Kalau ditanya
dia bisanya apa, masih tidak jelas juga apa
yang dilakukannya dulu, apakah bisa men-
gobati atau seperti apa, tidak diketahui. Tapi
katanya, kalau orang tersesat dalam hutan
dahulu, ada yang bisa melihat rumah Inada
Silowo, tapi rumah itu tidak bisa dijangkau."

Berdasarkan keterangan di atas, local genius yang terkait dengan pengarusutamaan gender di daerah Nias Selatan masih sangat sedikit sekali. Dalam FGD, ketika mendiskusikan mengenai pekerjaan yang terkait dengan perempuan dalam masyarakat Nias Selatan, selain urusan domestik rumah tangga dan bertani, perempuan juga ahli dalam hal kerajinan tangan. Kerajinan tangan ini banyak digunakan dan dipromosikan oleh pemerintah daerah Kabupaten Nias Selatan, dalam hal ini Bidang Pariwisata dalam seremonial penyambutan kunjungan pejabat dan menjadi souvenir bagi wisatawan yang berkunjung ke Nias Selatan. Bentuk kerajinan tangan seperti bolanafo, kemudian anyaman akar, kerajinan kulit penyu, dan pahatan tempurung kelapa, yang biasa dikerjakan oleh perempuan, di beberapa daerah masih dipertahankan dan dibina di bawah Bidang Pariwisata Kabupaten Nias Selatan.
Nias Selatan yang juga terkenal dengan wisata budaya peninggalan zaman megalitikum sudah pasti erat kaitannya dengan nilai-nilai budaya, local genius yang dijadikan program pemerintah Kabupaten Nias Selatan dalam RPJMD tentang Pengembangan Nilai Budaya Pengelolaan Kekayaan Budaya, peran perempuan dalam hal ini menjadi penyambut tamu dengan tari-tarian seperti tarian moyo.

Pada bidang kesehatan, local genius yang masuk dalam RPJMD pemerintah Kabupaten Nias Selatan mengenai Pengembangan Obat Asli Indonesia, khususnya Nias Selatan. Obatobatan asli khas Nias Selatan ini tidak hanya terkait dengan perempuan, tetapi juga untuk seluruh masyarakat Nias.

\section{Simpulan dan Saran}

Pemerintah daerah Karo dan Nias Selatan belum melakukan identifikasi mengenai local genius mana yang memiliki nilai lebih dan dapat dikembangkan dalam RPJMD. Pemerintah daerah Karo dan Nias Selatan belum memahami secara lengkap konsep pengarusutamaan gender. Local genius pada masyarakat Karo lebih banyak teraplikasi dalam bentuk ritual adat, sedangkan pada masyarakat Nias Selatan, local genius biasanya dalam bentuk mitos dan ritual adat dominan dilaksanakan oleh kalangan bangsawan. Peran gender dalam budaya patrilineal dalam masyarakat Karo melibatkan lelaki dan perempuan cenderung seimbang, sedangkan peran gender dalam budaya patrilineal Nias Selatan masih mengalami ketimpangan.

Ada beberapa nilai-nilai local genius yang dimasukkan Pemerintah Kabupaten Karo dan Nias Selatan dalam RPJMD-nya seperti: Pengembangan tanaman obat tradisional, dan pengembangan nilai budaya pengelolaan kekayaan budaya. Sangat diperlukan penelitian model dinamis untuk menggali nilai-nilai local genius yang dapat dikembangkan dalam program kebijakan pemerintah Karo dan Nias Selatan. Perlu juga sosialisasi pemahaman konsep gender bagi para pembuat kebijakan pemerintah Karo dan Nias Selatan.

\section{Daftar Pustaka}

Keraff, Sony. (2002). Etika Lingkungan. Jakarta: Gramedia 
Maria Ulfah Subadio, T.O Ihromi ed.., (1978). Peranan Kedudukan Wanita Indonesia., Yogyakarta: Universitas Gajah Mada

Muljono, Slamet. (2006). Tafsir Sejarah Nagara Kretreligi. Yogyakarta:LkiS

Nababan, A. (2003). Pengelolaan Sumberdaya Alam Berbasis Masyarakat Adat. Pelatihan Pengelolaan Lingkungan Hidup Daerah. Bogor: Pusat Penelitian Lingkungan Hidup IPB

Promono, Djoko. (2005). Budaya Bahari Pemda Sulsel. Dinas pariwisata Jakarta: Gramedia

Sibarani, Robert. (2004). Antropolinguistik. Medan: Poda

Tangkilisan. Hesel Nogi S., (2003). Kebijakan Publik yang Membumi. Lukman Offset bekerja sama dengan Yayasan Pembaruan Administrasi Publik Indonesia, Yogyakarta
Tsing, Anna Lowenhaupt. (1998). Dibawah Bayang-Bayang Ratu Intan, Proses Marjinalisasi Pada Masyarakat Terasing. Jakarta.Yayasan Obor Indonesia.

Jurnal:

Elisa Susanti, (2010). Penerapan Performance Budgeting di Indonesia. Jurnal AdministrasiNegara, Vol.1, No.2:264-277. STIALAN, Bandung

Nurhaeni, Ismi Dwi Astuti, dkk. (2011). Efektivitas Implementasi Kebijakan Anggaran Responsif Gender. Jurnal Ilmu Administrasi Negara, Volume 11, Nomor 1 , Januari 2011

Sodani, P.R. and Sharma, Shilpi. (2008). "Gender Responsive Budgeting" Journalof HealthManagement Vol.10, No. 2 